\title{
Article
}

\section{The Trichohyalin-Like Protein Scaffoldin Is Expressed in the Multilayered Periderm during Development of Avian Beak and Egg Tooth}

\author{
Veronika Mlitz $^{1}$ (D), Marcela Hermann ${ }^{2}$, Maria Buchberger ${ }^{1}$, Erwin Tschachler ${ }^{1}$ and Leopold Eckhart ${ }^{1, *(D)}$ \\ 1 Skin Biology Laboratory, Department of Dermatology, Medical University of Vienna, 1090 Vienna, Austria; \\ veronika.mlitz@meduniwien.ac.at (V.M.); maria.buchberger@meduniwien.ac.at (M.B.); \\ erwin.tschachler@meduniwien.ac.at (E.T.) \\ 2 Department of Medical Biochemistry, Medical University of Vienna, 1090 Vienna, Austria; \\ marcela.hermann@meduniwien.ac.at \\ * Correspondence: leopold.eckhart@meduniwien.ac.at
}

Citation: Mlitz, V.; Hermann, M.; Buchberger, M.; Tschachler, E.; Eckhart, L. The Trichohyalin-Like Protein Scaffoldin Is Expressed in the Multilayered Periderm during Development of Avian Beak and Egg Tooth. Genes 2021, 12, 248. https:// doi.org/10.3390/genes12020248

Academic Editor: Roger H. Sawyer Received: 30 December 2020

Accepted: 6 February 2021

Published: 10 February 2021

Publisher's Note: MDPI stays neutral with regard to jurisdictional claims in published maps and institutional affiliations.

Copyright: (c) 2021 by the authors. Licensee MDPI, Basel, Switzerland. This article is an open access article distributed under the terms and conditions of the Creative Commons Attribution (CC BY) license (https:// creativecommons.org/licenses/by/ $4.0 /)$.

\begin{abstract}
Scaffoldin, an S100 fused-type protein (SFTP) with high amino acid sequence similarity to the mammalian hair follicle protein trichohyalin, has been identified in reptiles and birds, but its functions are not yet fully understood. Here, we investigated the expression pattern of scaffoldin and cornulin, a related SFTP, in the developing beaks of birds. We determined the mRNA levels of both SFTPs by reverse transcription polymerase chain reaction (RT-PCR) in the beak and other ectodermal tissues of chicken (Gallus gallus) and quail (Coturnix japonica) embryos. Immunohistochemical staining was performed to localize scaffoldin in tissues. Scaffoldin and cornulin were expressed in the beak and, at lower levels, in other embryonic tissues of both chickens and quails. Immunohistochemistry revealed scaffoldin in the peridermal compartment of the egg tooth, a transitory cornified protuberance (caruncle) on the upper beak which breaks the eggshell during hatching. Furthermore, scaffoldin marked a multilayered peridermal structure on the lower beak. The results of this study suggest that scaffoldin plays an evolutionarily conserved role in the development of the avian beak with a particular function in the morphogenesis of the egg tooth.
\end{abstract}

Keywords: keratinocytes; epidermis; trichohyalin; birds; beak; rhamphotheca; periderm; egg; development; evolution

\section{Introduction}

The embryonic development of birds and most reptiles occurs in eggs. Hatching is a crucial step in the life of these sauropsids and depends on the active breaking of the eggshell (Figure 1A). In squamate reptiles, a true tooth is used to open the egg [1,2], whereas in turtles, alligators and birds (together archelosaurs), a cornified carnuncle located on the upper beak or jaw is instrumental for hatching [3,4]. This caruncle is commonly referred to as the egg tooth, although it is not related to true teeth but rather consists of keratinocytes accumulating specific keratins and corneous $\beta$-proteins (CBPs), also known as $\beta$-keratins [5-7]. The caruncle-type egg tooth is the first cornified integumentary structure to appear during the embryonic development of birds [8]. Maturation of the egg tooth leads to its hardening which is completed before hatching. Later, the cornification of the rhamphotheca (beak) is completed and the egg tooth is lost (Figure 1A). Despite its critical role for the life of birds, the molecular control of egg tooth development in relation to development of the beak is only incompletely known [9].

The development of cornified skin appendages and the formation of the cornified layer of the epidermis depend on the differentiation of epidermal keratinocytes [10-12]. A gene cluster, known as the epidermal differentiation complex (EDC), plays crucial roles in the cornification of keratinocytes in mammals, reptiles and birds [13-17]. One class of EDC 
genes consists of one non-coding and one protein-coding exon. Examples include CBPs, epidermal differentiation cysteine-rich protein (EDCRP), epidermal differentiation protein starting with a MTF motif and rich in histidine (EDMTFH) and epidermal differentiation protein containing DPCC motifs (EDDM) which have been detected in feathers and other cornified skin appendages of birds and reptiles [17-20]. The other class of EDC genes is the S100 fused-type protein (SFTP) gene family which consists of one non-coding and two coding exons (Figure 1B).

A

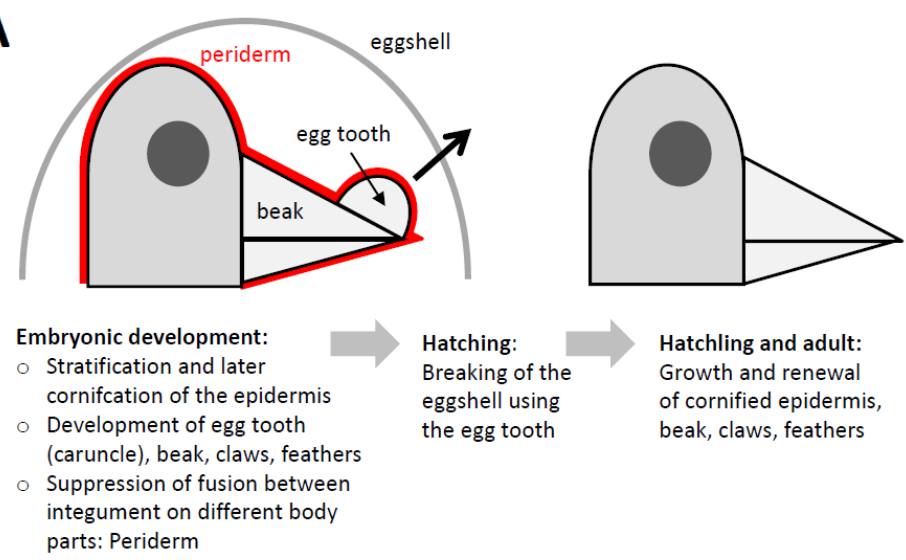

B

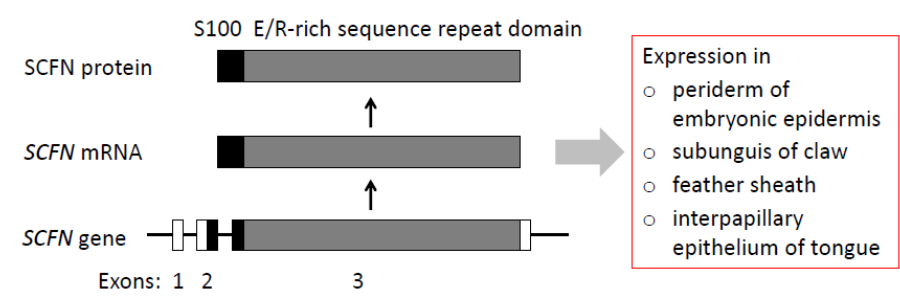

Figure 1. Schematic overview of beak development and SFTP gene expression. (A) Schematic depiction of the development and function of avian beak and egg tooth. (B) Organization and expression of the avian scaffoldin (SCFN)/trichohyalin-like gene, mRNA and protein. E, glutamic acid; $R$, arginine.

SFTP genes give rise to proteins composed of a conserved N-terminal S100 domain, containing two calcium-binding EF-hand motifs, a central repeat domain of varying length and a protein-specific carboxy (C)-terminal domain. The C-terminal domain was suggested to contribute to the specific functions of each SFTP. In humans, seven SFTP proteins, filaggrin (FLG), filaggrin-2 (FLG2), trichohyalin (TCHH), trichohyalin-like1 (TCHHL1), hornerin (HRNR), repetin (RPTN) and cornulin (CRNN), have been identified. FLG, CRNN and TCHH have been best characterized $[13,14]$. FLG induces keratin filament aggregation in the upper layers of the epidermis, UV protection and hydration of the stratum corneum [21-23]. Polymorphisms in the FLG gene are associated with ichthyosis vulgaris and atopic dermatitis [24]. CRNN is expressed in the upper layers of the esophagus and epidermis as well as the inner root sheath of the hair follicle [25]. TCHH was also described as a keratin intermediate filament-associated protein that mechanically strengthens specific epithelia such as the inner root sheath of the hair follicle, the filiform papillae of the tongue or the nail isthmus [26,27]. Mutations of TCHH cause uncombable hair syndrome [28].

Recently, SFTPs were identified in birds, reptiles and amphibians [29,30], indicating that SFTPs are evolutionary ancient proteins required for terrestrial life. While turtles, geckos, alligators and chickens have two SFTP genes, CRNN and Scaffoldin (SCFN), also referred to as Trichohyalin-like [29,31], three SFTP genes, CRNN, SCFN1 and SCFN2, are present in snakes [32] and only SCFN is present in the anole lizard [29,33], songbirds 
(Passeri), cormorants and Accipitriformes (eagles, hawks, vultures, secretary birds and relatives) [34]. Screening for SFTP expression sites in the chicken revealed CRNN or SCFN in the subunguis of claws, the feather sheath, epithelial cells located between papillae of the tongue and in the embryonic periderm (Figure 1B). The embryonic beak including the egg tooth yielded positive signals for SCFN [29] which prompted us to perform more detailed studies that are reported in the present manuscript.

Here, we investigate the expression of SFTPs during embryonic development of the beak and the egg tooth in chickens and quails. We report a conserved expression of SCFN in peridermal compartments of the upper and lower beak, suggesting a role in early development of the avian beak and egg tooth.

\section{Materials and Methods}

\subsection{Animals}

Tissue samples were prepared from chicken embryos and adult animals that were sacrificed in a previously published study [19]. Chicks were purchased from Schropper $\mathrm{GmbH}$, Gloggnitz, Austria. Fertilized quail eggs were obtained from the Research Institute of Molecular Pathology, Vienna, Austria, in the course of a study published previously [35]. The eggs were incubated under standard conditions at $37.5^{\circ} \mathrm{C}$ and $60-70 \%$ humidity. Prehatch eggs were removed at days 10, 14 or 18 (chicken) or 8,10 or 14 (quail) of development. The shell of eggs was cut open to expose the embryo for tissues preparation.

All animal procedures were conducted according to the guidelines established by the Animal Care and Use Committee of the Medical University of Vienna. The Ethics Committee of the Medical University of Vienna decided that, in agreement with the national laws, a permission for sacrificing animals for organ preparation was not required.

\subsection{RNA Extraction, $c D N A$ Synthesis and Real-Time PCR}

RNA was extracted from tissues that were homogenized with the Precellys system (VWR International, Radnor, PA, USA) using peqGOLD TriFast ${ }^{\mathrm{TM}}$ (VWR). Of note, RNA extraction from embryonic skin appendages was more efficient than extraction from fully cornified and hardened adult tissues. In brief, tissues were stored in RNAlater (Thermofisher, Vienna, Austria), cut into small pieces with sterile scalpels and incubated in $1 \mathrm{~mL}$ TriFast (VWR) on ice before and after homogenization. The tissue homogenizing Kit CK14 containing $1.4 \mathrm{~mm}$ ceramic beads (Precellys, VWR) was used for 2 treatments at $5500 \mathrm{rpm}$ for $45 \mathrm{~s}$. RNA was prepared with TriFast (VWR) and reverse-transcribed into cDNA using an iScript cDNA synthesis kit (Bio-Rad, Hercules, CA, USA) according to the manufacturers' instructions. Real-time PCR was performed using the LightCycler ${ }^{\circledR}$ technology and the LightCycler 480 SYBR Green I Master Kit (Roche Applied Science, Basel, Switzerland) according to the manufacturer's protocol. CRNN cDNA of both chickens and quails was amplified with the following intron-spanning primer pair Crnn_f (5'-CAGGAGTTTGGGGATGTGAT-3') and Crnn_r (5'-TTCTGGCTCCAGGTACTGCT$\left.3^{\prime}\right)$. Chicken SCFN and the house-keeping gene HPRT1 were amplified with c-Scfn_f (5'-AGGAAGGCACAATCAACCAC-3') and c-Scfn_r $\left(5^{\prime}\right.$-CACGACAAACCTCTGCTTCA-3') and c-Hprt1-f (5'-AAAGTCATTGGTGGGGATGA-3') and c-Hprt1-r (5'-GTAGTCGAGGGCGTATCCAA $-3^{\prime}$. Quail SCFN and GAPDH [36] were amplified with the primers q-Scfn_f (5'-GGAAGATGGAGACCAATCCA-3') and q-Scfn_r $\left(5^{\prime}\right.$-CAGGCCTTAGCCACTCTGAA-3') and q-Gapdh_f ( $5^{\prime}$-CTAAGGCTGTGGGGAAGGTCA-3') and q-Gapdh_r ( $5^{\prime}$ - CATCAAAGGTGGAGGAATGGC- $3^{\prime}$ ). The expression levels of $C R N N$ and SCFN mRNA were normalized to the expression levels of housekeeping genes in each tissue, as described previously [37]. The relative expression levels in different tissues were defined as the ratio of expression in each tissue relative to that in an arbitrarily selected tissue.

\subsection{Histological Staining and Immunohistochemistry}

Tissues were fixed in formaldehyde and embedded in paraffin according to published protocols [29]. Hematoxylin and eosin staining was performed as reported previously [29]. 
The generation of the mouse anti-SCFN polyclonal serum directed against the peptide RYERTREDIAAEAE within the repeat unit in the C-terminal domain of chicken SCFN (Supplementary Figure S1A) was reported previously [29]. The epitope is conserved with the exception of 1 amino acid residue in SCFN of the quail (Supplementary Figure S1B,C). Immunohistochemistry with antiserum dilutions of 1:2000 (chicken) and 1:500 (quail) gave specific signals. The specific immunoreactivity was blocked by preincubation with antigenic peptide ( $4 \mu \mathrm{g}$ peptide per $1 \mu \mathrm{L}$ antiserum).

\subsection{In Situ Hybridization}

Tissue samples were fixed in formaldehyde and embedded in paraffin. There was no special treatment depending on the hardness of the samples. Hard cornified skin appendages were difficult to cut and to maintain in good shape during further processing, whereas samples from earlier stages of development were generally useful. The samples were sectioned at $5 \mu \mathrm{m}$ thickness and mounted on Superfrost Ultra slides (Thermo Scientific). The sections were deparaffinized by melting at $58{ }^{\circ} \mathrm{C}$ for $1 \mathrm{~h}$, followed by incubation in xylol for $2 \times 15 \mathrm{~min}$ and an alcohol series (100\%, 90\%, 80\%, 70\%, 30\% ethanol). After washing in phosphate-buffered saline (PBS) for $3 \mathrm{~min}$, the sections were fixed in freshly prepared $4 \%$ paraformaldehyde in PBS on ice for $20 \mathrm{~min}$. Then, the sections were washed with PBS for $2 \times 3 \mathrm{~min}$ and incubated in $100 \mathrm{mM} \mathrm{HCl}$ at room temperature for $10 \mathrm{~min}$. After washing with PBS for $2 \times 3 \mathrm{~min}$, the samples were incubated in $2 \times$ saline sodium citrate (SSC) at $70{ }^{\circ} \mathrm{C}$ for $30 \mathrm{~min}$. Subsequently, the samples were washed with PBS for $2 \times 3 \mathrm{~min}$ and digested with proteinase $\mathrm{K}(20 \mu \mathrm{g} / \mathrm{mL}$ in $50 \mathrm{mM}$ Tris $\mathrm{HCl})$ at $37^{\circ} \mathrm{C}$. After washing with PBS for $2 \times 3 \mathrm{~min}$, the samples were fixed with $4 \%$ paraformaldehyde in PBS on ice for $20 \mathrm{~min}$, washed again with PBS and subjected to acetylation by 10-min incubation in $200 \mathrm{~mL} 0.1 \mathrm{M}$ triethanolamine, $\mathrm{pH} 8$, containing $500 \mu \mathrm{L}$ acetic anhydride. Finally, the samples washed with PBS for $2 \times 3$ min, dehydrated in $30 \%, 70 \%, 80 \%, 90 \%$ and $100 \%$ ethanol and air-dried for $1 \mathrm{~h}$. The slides were stored at $-20{ }^{\circ} \mathrm{C}$ until hybridization with the probes.

As pretreatment before hybridization, the sections were incubated with hybridization solution at $55{ }^{\circ} \mathrm{C}$ for $1 \mathrm{~h}$. A 30-mL stock of hybridization solution was made by mixing water and $15 \mathrm{~mL}$ deionized formamide (VWR), $6 \mathrm{~mL} 20 \times \mathrm{SSC}$ (Sigma), $3 \mathrm{~g}$ dextran sulphate (Sigma, St. Louis, MO, USA), 0.3 mL 50× Denhardt's solution (Sigma), 3 mL 10× sodium phosphate buffer, $75 \mu \mathrm{L}$ denatured salmon sperm DNA $(10 \mathrm{mg} / \mathrm{mL}$, Life Technologies, Waltham, MA, USA) and $15 \mathrm{mg}$ yeast t-RNA (Life Technologies).

Generation and validation of digoxigenin (DIG)-labeled sense and antisense probes for CRNN were reported previously [29]. DIG-labeled probes were denatured and mixed with hybridization solution at $80^{\circ} \mathrm{C}$ and then incubated on ice for $10 \mathrm{~min}$. Antisense and sense probes were applied to the pretreated sections at concentrations of 5 and $10 \mathrm{ng} / \mathrm{mL}$, respectively, at a hybridization temperature of $55^{\circ} \mathrm{C}$ [29]. After $20 \mathrm{~h}$ of incubation, the sections were washed with $2 \times \mathrm{SSC}$ for $1 \mathrm{~min}, 3$ times with $2 \times \mathrm{SSC}+50 \%$ formamide at $54{ }^{\circ} \mathrm{C}$ for $20 \mathrm{~min}$, once with $2 \times \mathrm{SSC}$ for $10 \mathrm{~min}$ and once with $0.2 \times \mathrm{SSC}$ for $10 \mathrm{~min}$. Subsequently, the DIG labels were detected immunochemically. The samples were incubated in a buffer containing TRIS $(0.1 \mathrm{M}) \mathrm{pH} 7.5, \mathrm{NaCl}(1.15 \mathrm{M})$ and $2 \%$ bovine serum albumin (BSA) at room temperature for 15 min followed by incubation with anti-DIG-AP Fab-fragment (1:250, Roche) for $1 \mathrm{~h}$. After washing in the aforementioned buffer for 2 times $5 \mathrm{~min}$, samples were incubated with a buffer containing TRIS $(0.1 \mathrm{M}), \mathrm{NaCl}(0.1 \mathrm{M})$ and $\mathrm{MgCl}_{2}(0.05 \mathrm{M})$, pH 9.5. Finally, nitro blue tetrazolium (NBT)/5-bromo-4-chloro-3-indolyl-phosphate (BCIP) (Roche) was added at a dilution of $20 \mu \mathrm{L} / \mathrm{mL}$ and the samples were incubated at room temperature in the dark until color development. Stainings obtained with the antisense probe were considered specific when the incubation of a serial section with the sense probe did not yield a staining signal. 


\section{Results}

\subsection{Avian SFTPs Are Expressed during Embryonic Beak Development of Chicken and Quail}

To investigate the expression of the two SFTPs during avian embryonic development, we determined SCFN and CRNN mRNA levels in embryonic tissues of chickens and quails at different stages of development. CRNN and SCFN mRNAs were detected by RT-PCR in embryonic beak, skin, feathers and claws in both chickens and quails (Figures 2 and 3). Although limited availability of samples did not allow statistical analysis of differences in this exploratory part of the study, high levels of CRNN and SCFN expression were consistently found in the egg tooth of both chickens (Figure 2) and quails (Figure 3).

To localize the expression of $C R N N$, we performed mRNA in situ hybridization in chicken embryos. CRNN mRNA was readily detectable in the multilayered periderm close to the tips of the upper and lower beak on embryonic day E10 of chicken development (Figure 4). Other parts of the beak where the keratinization and peridermal development was less progressed did not show CRNN labeling.

A

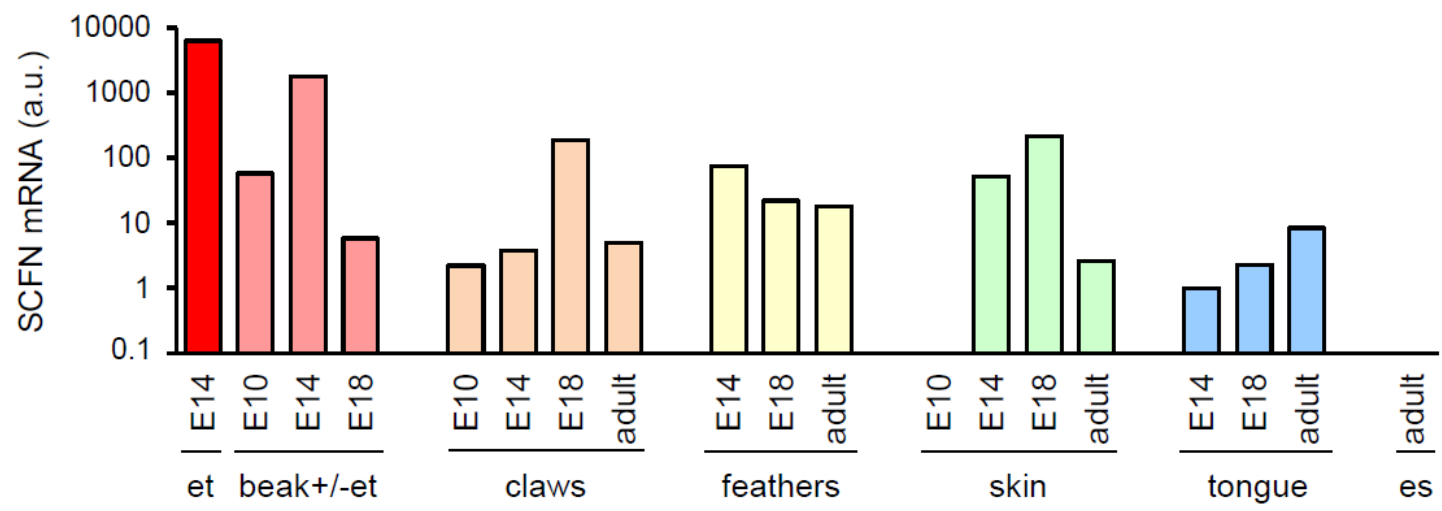

B

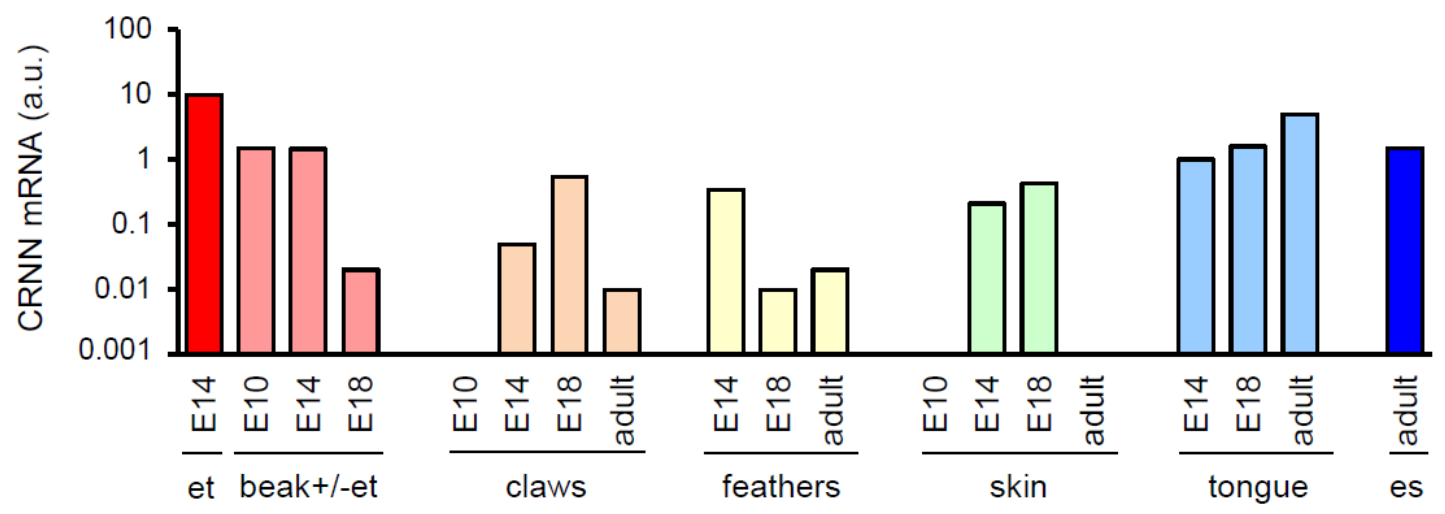

Figure 2. Expression of chicken SFTP mRNAs during embryonic development. RNA was extracted from indicated tissues of adult chicken and chicken embryos at developmental stages E10, E14 and E18. Following cDNA synthesis, real-time PCRs were performed. mRNA levels of SCFN (A) and CRNN (B) are shown in arbitrary units (a.u.) which were calculated by normalization to the housekeeping gene HPRT1 in the same tissue and dividing the normalized value of each tissue by the normalized expression level in the tongue sample of stage E14. At developmental stage E14, the beak of the embryo was separated into two different parts—-the egg tooth (et) and the remaining beak. es, esophagus. 
A

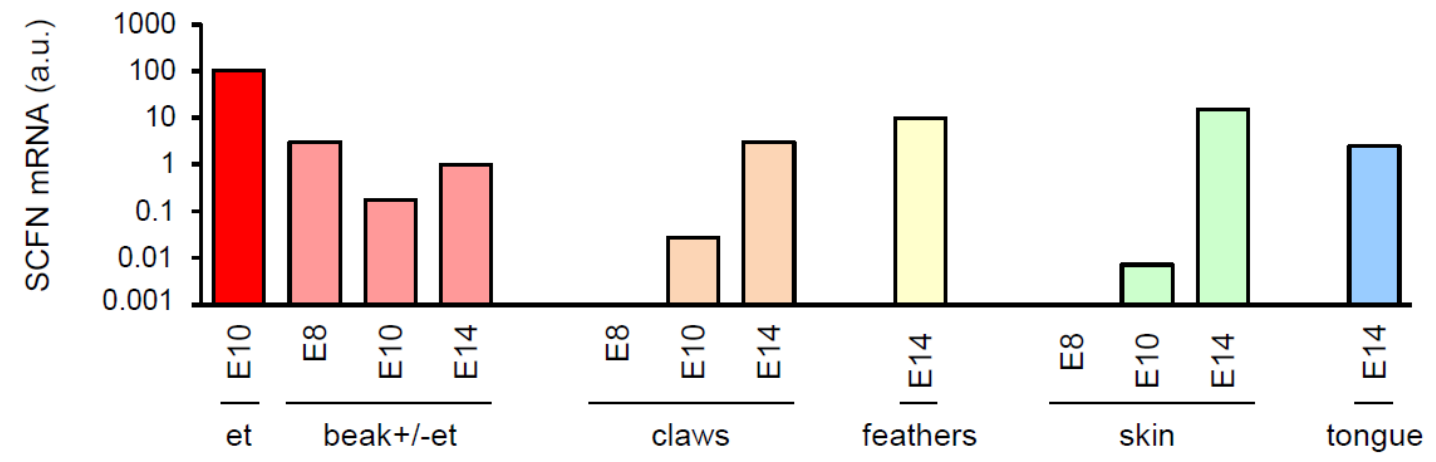

B

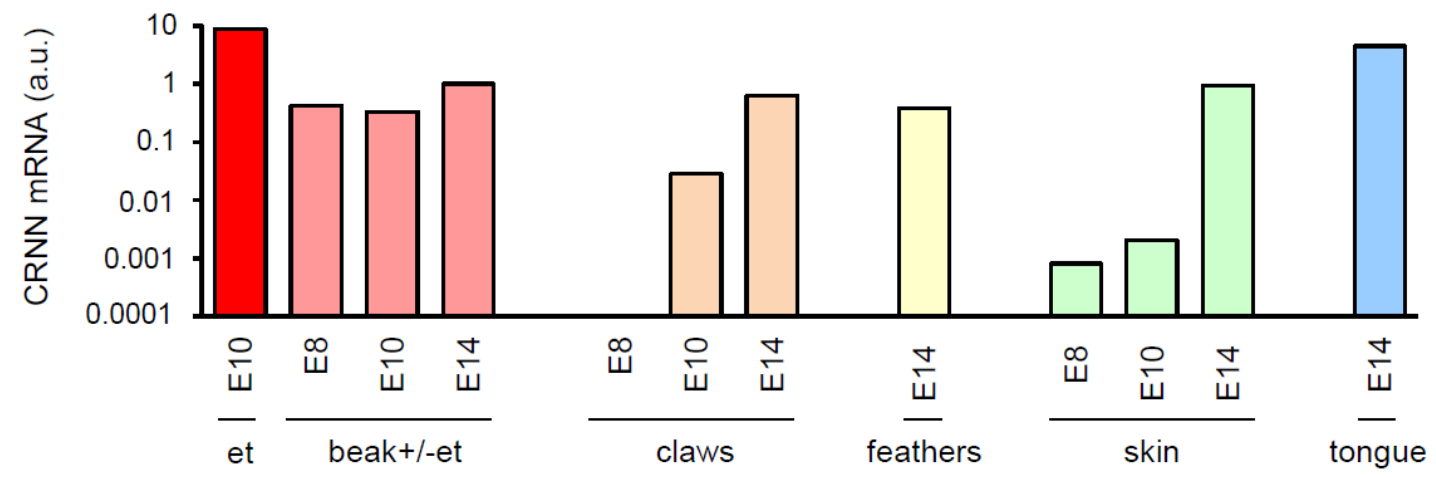

Figure 3. SFTP mRNAs expressed during embryonic development of quails. Indicated tissues were collected from quail embryos at developmental stages E8, E10 and E14, RNA was extracted, re-transcribed into cDNA and real-time PCRs were performed. mRNA levels of SCFN (A) and CRNN (B) are shown in arbitrary units (a.u.) which were calculated by normalization to the housekeeping gene HPRT1 in the same tissue and dividing the normalized value of each tissue by the normalized expression level in the beak sample of stage E14. The RNA of the egg tooth (et) and the remaining beak of the E10 embryo was extracted separately.
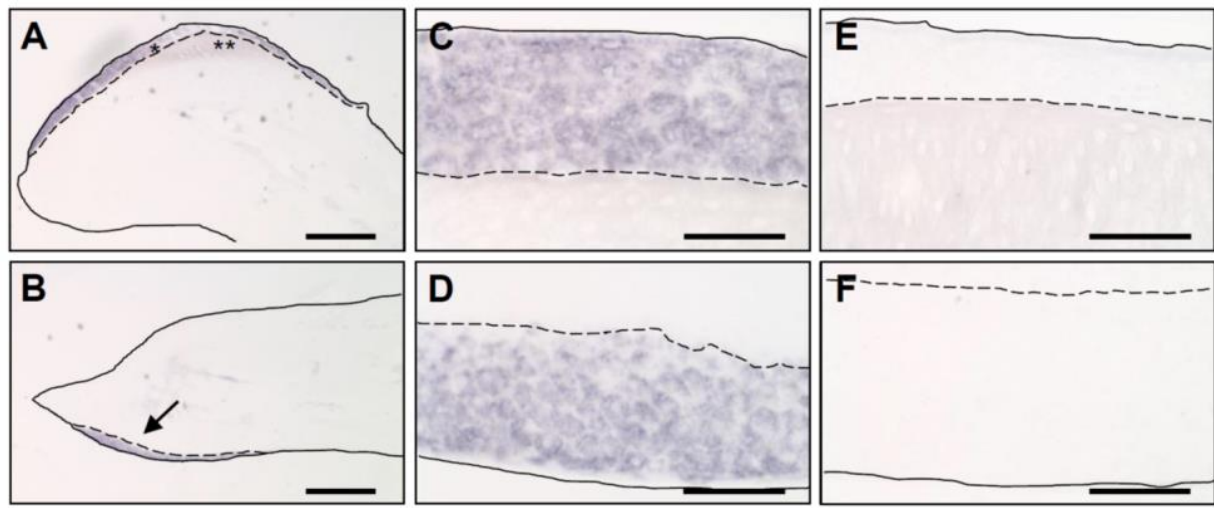

Figure 4. CRNN mRNA is expressed in the peridermal compartment of the chicken egg tooth. To localize CRNN mRNA-expressing tissues, an in situ hybridization of sections through the beak of chicken embryos at developmental stage E10 was performed. Pictures of the upper beak (A, higher magnification $\mathbf{C})$ and lower beak (B, higher magnification $\mathbf{D})$ are shown. The signal detected in the lower beak is indicated by an arrow (B). As negative control, the sense probe was applied to the upper (E) and lower beak (F). ${ }^{*}$, peridermal compartment of the egg tooth; ${ }^{* *}$, cornified egg tooth. Bars: $400 \mu \mathrm{m}(\mathbf{A}, \mathbf{B}), 40 \mu \mathrm{m}(\mathbf{C}-\mathbf{F})$. 


\subsection{SCFN Forms Granules in Multilayered Periderm on the Beak}

To determine the expression pattern of SCFN at the protein level, we used an antiserum that had been raised against an epitope of chicken SCFN [29]. This antiserum was predicted to cross-react with quail SCFN because of more than $90 \%$ sequence conservation of the epitope (Supplementary Figure S1). In the chicken, SCFN was detected in the multilayered periderm around the egg tooth (Figure $5 \mathrm{D}, \mathrm{E}$ ). It formed granules that corresponded in size and distribution to eosinophilic periderm granules [38] (Figure 5A-C), supporting the conclusion of a previous study that identified SCFN as a major component of granules in the periderm covering the embryonic epidermis [39]. A similar distribution of eosinophilic periderm granules (Figure 6A,B) and accumulation of SCFN were observed on the upper embryonic beak of quails (Figure 6E,F).

Histological investigation of the lower beak of chickens and quails revealed that the periderm was multilayered and contained eosinophilic granules similar to the pattern on the upper beak (Figures 5B,C and 6C,D). Immunostaining demonstrated SCFN as a component of these granules in both species investigated (Figures 5E and 6G-I). Preadsorption of the serum with the antigen blocked the immunostaining (Figure $5 \mathrm{~F}, \mathrm{G}$ ), confirming its specificity. These data suggest that SCFN plays an evolutionarily conserved role in the development of the upper and lower beak in chickens and quails.
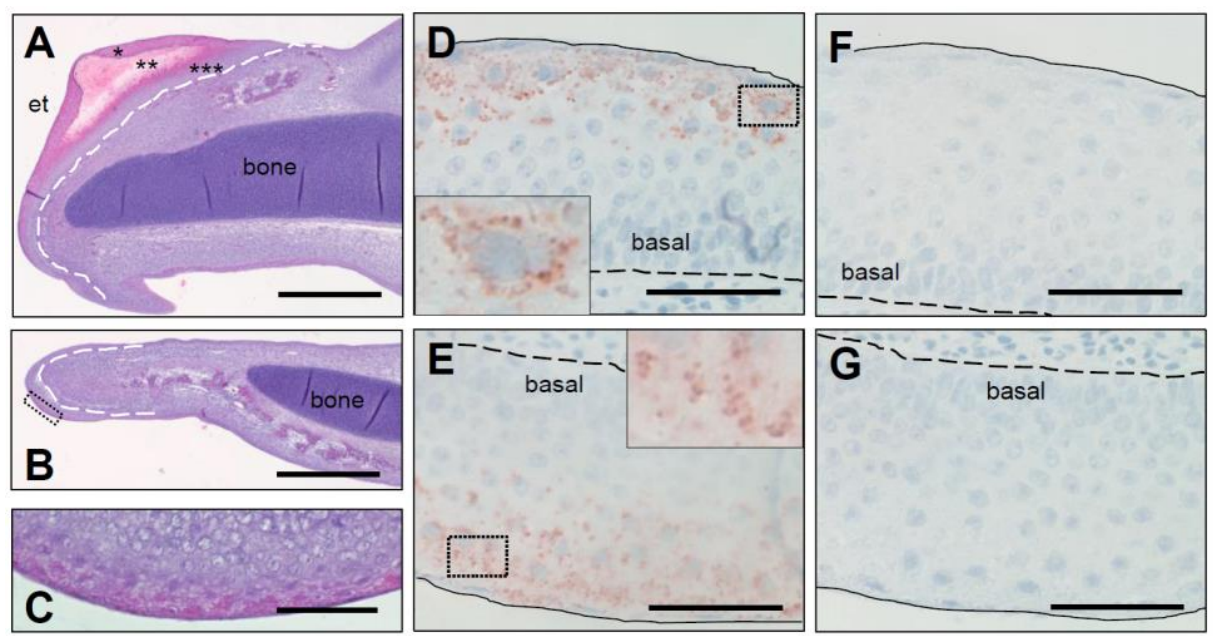

Figure 5. Expression of SCFN protein in the embryonic chicken egg tooth. Sections through the upper beak $(\mathbf{A}, \mathbf{D}, \mathbf{F})$ and the lower beak $(\mathbf{B}, \mathbf{C}, \mathbf{E}, \mathbf{G})$ of chicken embryos at developmental stage E10 were immunohistologically stained with hematoxylin and eosin $(\mathbf{A}-\mathbf{C})$ or with mouse anti-SCFN serum $(\mathbf{D}, \mathbf{E})$. As control, anti-SCFN was blocked with the immunogen $(\mathbf{F}, \mathbf{G})$. The box in B indicates the area shown in a higher magnification in C. Insets in D and E show higher magnification of SCFN granules from the boxed areas of the sections. ${ }^{*}$, peridermal compartment of the egg tooth; ${ }^{* *}$, cornified egg tooth; ${ }^{* *}$, beak underneath the egg tooth. et, egg tooth. Bars: $400 \mu \mathrm{m}(\mathbf{A}, \mathbf{B}) ; 40 \mu \mathrm{m}(\mathbf{C}-\mathbf{G})$. 

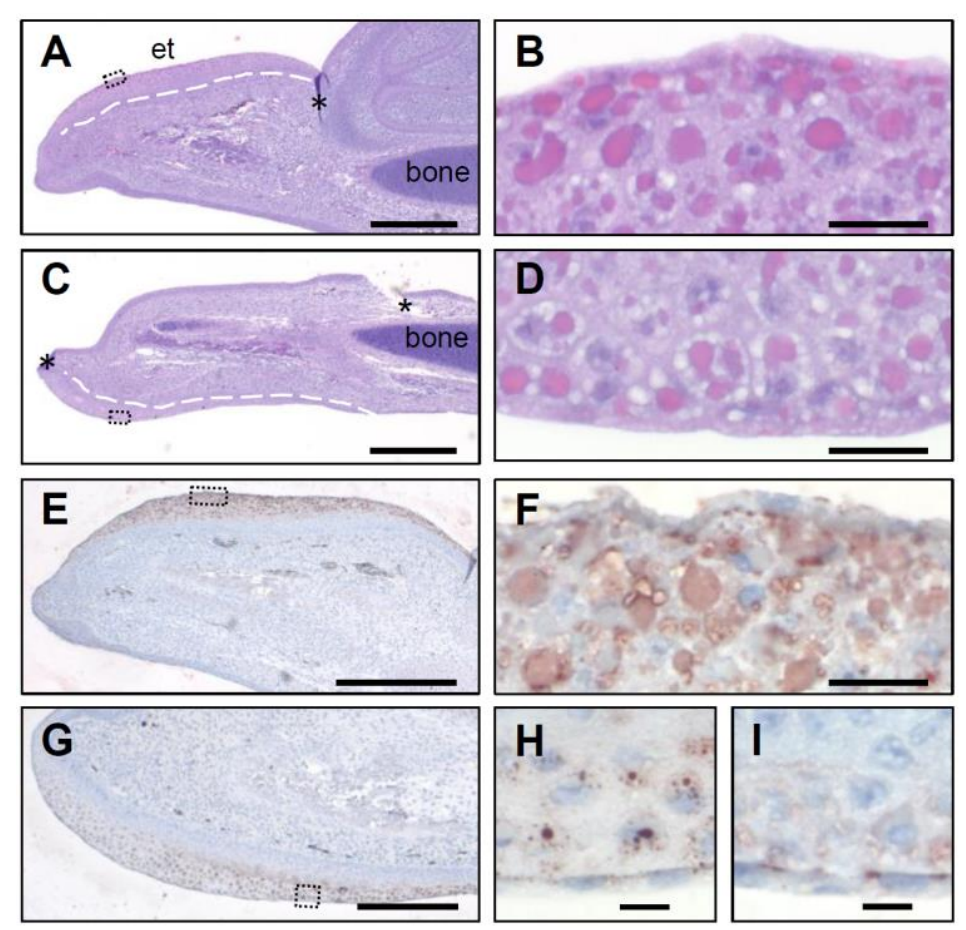

Figure 6. SCFN protein is expressed in the peridermal compartment of the quail egg tooth. Tissues were collected from quails at embryonic development stage E10. Hematoxylin and eosin stains of the upper (A,B) and lower beak (C,D) are shown. To localize SCFN protein in the quail beak, an immunohistochemical staining of SCFN was performed in the upper $(\mathbf{E}, \mathbf{F})$ and the lower quail beak $(\mathbf{G}, \mathbf{H})$. As control for the specificity of the result, anti-SCFN serum was blocked with the immunogenic peptide (I). Boxes in A, C, E and G indicate the region shown at higher magnification in B, D, F and $\mathbf{H}$, respectively. Asterisks in $\mathbf{A}$ and $\mathbf{C}$ mark artefacts caused by the sectioning. Broken lines in $\mathbf{A}$ and $\mathbf{C}$ indicate border of periderm. et, egg tooth. Bars: $400 \mu \mathrm{m}(\mathbf{A}, \mathbf{C}, \mathbf{E}) ; 200 \mu \mathrm{m}(\mathbf{G}) ; 20 \mu \mathrm{m}(\mathbf{B}, \mathbf{D}, \mathbf{F})$; $10 \mu \mathrm{m}(\mathbf{H}, \mathbf{I})$.

\section{Discussion and Conclusions}

The results of this study demonstrate that both CRNN and SCFN are expressed during the development of the integument of the avian beak. SCFN could be detected at the protein level in two species and consistently appeared in a granular pattern. Both SFTPs were expressed in the peridermal scaffold of the forming egg tooth but also on the lower beak. According to a comprehensive review article by Clark [40], an egg tooth-like structure is formed on the lower beak of diverse species of birds, such as the cormorant (Phalacrocorax auritus), red kite (Milvus milvus), common moorhen (Gallinula chloropus), southern black korhaan (Afrotis afra), northern lapwing (Vanellus vanellus), black-tailed godwit (Limosa limosa), pied avocet (Recurvirostra avosetta) and mourning dove (Zenaida macroura), and an egg tooth anlage is present on the lower beak of the chick. Therefore, it is likely that the accumulation of peridermal layers and the expression of SCFN during development of the lower beak correspond to the growth of an egg tooth-like structure which, however, needs further characterization.

As our immunohistochemical data suggest that a modification of the periderm supports the development of the egg tooth on the beak, this raises the question as to how these integumentary structures have evolved. The primordial and evolutionary ancient function of the periderm is to prevent the fusion between integumentary epithelia of different body parts [41]. The fact that a periderm lines the skin and the oral epithelia of fish [42] indicates that it has evolved prior to the water-to-land transition of tetrapods. In avian embryos, a one- or two-layered periderm covers the entire integument, including the beak [43], and SCFN and CRNN are expressed in this thin "conventional" periderm [29]. We propose 
that the multilayered periderm around the egg tooth has evolved from the normal thin periderm and the peridermal functions of SFTPs were maintained there.

Recently, it was suggested that the presence of a caruncle-type egg tooth in oviparous tetrapods allowed the repeated evolutionary loss of real teeth, i.e., edentulism, and the evolution of rhamphothecae (beaks) in turtles and birds [8]. Indeed, the existence of an egg tooth in beak-less tetrapods, such as crocodilians, supports the notion that the egg tooth is evolutionary older than the beak. It will be interesting to investigate whether the periderm also forms multiple layers around the developing egg tooth in turtles and crocodilians.

A recent large-scale study of genome sequences showed conservation of SCFN in birds, although the extremely long third exon of SCFN has not been completely or unambiguously sequenced in all bird genome sequences currently available [34]. By contrast, CRNN is absent or disrupted by mutations in songbirds and at least two other clades of birds, suggesting that the functions of CRNN are dispensable in these evolutionary lineages [34]. Accordingly, the expression of CRNN in the beak and egg tooth apparatus, though conserved in chickens and quails, may be functionally redundant with that of SCFN.

The protein features of SCFN are trichohyalin-like [26] with regard to the presence of a long C-terminal domain that is rich in glutamic acid (E) and arginine (R) which together constitute close to half of the total amino acid content of these proteins [29]. The presence of a double band on Western blots [29] indicates post-translational modification. The latter may change the isoelectric point (pI 5.3 predicted for chicken SCFN, GenBank accession number NP_001338424.2) and affect both interactions with other proteins and the affinity for histological dyes. Our results suggest that SCFN-positive periderm granules correspond to eosinophilic granules visible in hematoxylin and eosin stainings of the embryonic beak (Figures $5 \mathrm{~B}, \mathrm{C}$ and $6 \mathrm{C}, \mathrm{D}$ ). Besides modifications of SCFN, the presence of other proteins may influence the staining properties of these granules.

SFTPs were reported to interact with keratins, undergo cross-linking by transglutamination, serve as precursors for functional peptides and amino acids and contribute to degradation of the nucleus $[21,22,27,44,45]$. However, the relative importance of possible mechanisms of action are not known for mammalian SFTPs and even more so for avian SFTPs. The association of SCFN expression with important integumentary processes, such as development of the beak and egg tooth, indicates that SCFN should be a prime candidate for future studies of reverse genetics in birds.

Supplementary Materials: The following are available online at https:/ /www.mdpi.com/2073-442 5/12/2/248/s1, Figure S1: Sequences of S100 fused-type proteins (SFTPs) in chickens and quails.

Author Contributions: Conceptualization, V.M. and L.E.; methodology, V.M., M.H., M.B. and L.E.; data analysis, V.M. and L.E.; writing—original draft preparation, L.E.; writing—review and editing, V.M., M.H., M.B., E.T. and L.E.; project administration, L.E.; funding acquisition, L.E. All authors have read and agreed to the published version of the manuscript.

Funding: This work was supported by the Austrian Science Fund (FWF): P23801, P28004 and P32777. Open Access Funding by the Austrian Science Fund (FWF).

Institutional Review Board Statement: All animal procedures were conducted according to the guidelines established by the Animal Care and Use Committee of the Medical University of Vienna. The Ethics Committee of the Medical University of Vienna decided that, in agreement with the national laws, a permission for sacrificing animals for organ preparation was not required.

Informed Consent Statement: Not applicable.

Data Availability Statement: Data are contained within the article or Supplementary Material.

Acknowledgments: We thank Bahar Golabi for the excellent technical support.

Conflicts of Interest: The authors declare no conflict of interest. 


\section{References}

1. Fons, J.M.; Gaete, M.; Zahradnicek, O.; Landova, M.; Bandali, H.; Khannoon, E.R.; Richman, J.M.; Buchtová, M.; Tucker, A.S.; Landova, M. Getting out of an egg: Merging of tooth germs to create an egg tooth in the snake. Dev. Dyn. 2020, 249, 199-208. [CrossRef]

2. Lynch, V.J.; Wagner, G.P. Did egg-laying boas break Dollo's law? Phylogenetic evidence for reversal to oviparity in sand boas (Eryx, Boidae). Evolution 2010, 64, 207-216. [CrossRef]

3. Kingsbury, J.W.; Allen, V.G.; Rotheram, B.A. The histological structure of the beak in the chick. Anat. Rec. 1953, 116, 95-115. [CrossRef]

4. Alibardi, L. Cell proliferation, adhesion, and differentiation of keratinocytes in the developing beak and egg-tooth of the turtle Emydura macquarii. Protoplasma 2020, 257, 1433-1445. [CrossRef] [PubMed]

5. Shames, R.B.; Knapp, L.W.; Carver, W.E.; Sawyer, R.H. Region-specific expression of scutate scale type $\beta$ keratins in the developing chick beak. J. Exp. Zool. 1991, 260, 258-266. [CrossRef]

6. Alibardi, L. Immunodetection of type I acidic keratins associated to periderm granules during the transition of cornification from embryonic to definitive chick epidermis. Micron 2014, 65, 51-61. [CrossRef] [PubMed]

7. Wu, P.; Ng, C.S.; Yan, J.; Lai, Y.-C.; Chen, C.-K.; Lai, Y.-T.; Wu, S.-M.; Chen, J.-J.; Luo, W.; Widelitz, R.B.; et al. Topographical mapping of $\alpha$ - and $\beta$-keratins on developing chicken skin integuments, Functional interaction and evolutionary perspectives. Proc. Natl. Acad. Sci. USA 2015, 112, E6770-E6779. [CrossRef]

8. Wang, S.; Stiegler, J.; Wu, P.; Chuong, C.M.; Hu, D.; Balanoff, A.; Zhou, Y.; Xu, X. Heterochronic truncation of odontogenesis in theropod dinosaurs provides insight into the macroevolution of avian beaks. Proc. Natl. Acad. Sci. USA 2017, 114, 10930-10935. [CrossRef]

9. Nimmagadda, S.; Buchtová, M.; Fu, K.; Geetha-Loganathan, P.; Hosseini-Farahabadi, S.; Trachtenberg, A.J.; Kuo, W.P.; Vesela, I.; Richman, J.M. Identification and functional analysis of novel facial patterning genes in the duplicated beak chicken embryo. Dev. Biol. 2015, 407, 275-288. [CrossRef]

10. Sawyer, R.H.; Knapp, L.W.; O'Guin, M.W. The Skin of Birds. Biology of the Integument, Vertebrates. In Epidermis, DERMIS and Appendages; Bereither-Hahn, J., Matoltsy, A.G., Sylvia-Richards, R., Eds.; Springer: Berlin/Heidelberg, Germany, 1986; Volume 2, pp. 194-237.

11. Wu, P.; Hou, L.; Plikus, M.; Hughes, M.; Scehnet, J.; Suksaweang, S.; Widelitz, R.; Jiang, T.X.; Chuong, C.M. Evo-Devo of amniote integuments and appendages. Int. J. Dev. Biol. 2004, 48, 249-270. [CrossRef] [PubMed]

12. Alibardi, L. Embryonic keratinization in vertebrates in relation to land colonization. Acta Zool. 2009, 90, 1-17. [CrossRef]

13. Henry, J.; Toulza, E.; Hsu, C.Y.; Pellerin, L.; Balica, S.; Mazereeuw-Hautier, J.; Paul, C.; Serre, G.; Jonca, N.; Simon, M. Update on the epidermal differentiation complex. Front. Biosci. 2012, 17, 1517-1532. [CrossRef] [PubMed]

14. Kypriotou, M.; Huber, M.; Hohl, D. The human epidermal differentiation complex, cornified envelope precursors, S100 proteins and the 'fused genes' family. Exp. Dermatol. 2012, 21, 643-649. [CrossRef]

15. Greenwold, M.J.; Sawyer, R.H. Genomic organization and molecular phylogenies of the $\beta(\beta)$ keratin multigene family in the chicken (Gallus gallus) and zebra finch (Taeniopygia guttata), implications for feather evolution. BMC Evol. Biol. 2010, 10, 148. [CrossRef]

16. Greenwold, M.J.; Bao, W.; Jarvis, E.D.; Hu, H.; Li, C.; Gilbert, M.T.P.; Zhang, G.; Sawyer, R.H. Dynamic evolution of the $\alpha(\alpha)$ and $\beta(\beta)$ keratins has accompanied integument diversification and the adaptation of birds into novel lifestyles. BMC Evol. Biol. 2014, 14, 249. [CrossRef]

17. Strasser, B.; Mlitz, V.; Hermann, M.; Rice, R.H.; Eigenheer, R.A.; Alibardi, L.; Tschachler, E.; Eckhart, L. Evolutionary origin and diversification of epidermal barrier proteins in amniotes. Mol. Biol. Evol. 2014, 31, 3194-3205. [CrossRef]

18. Strasser, B.; Mlitz, V.; Hermann, M.; Tschachler, E.; Eckhart, L. Convergent evolution of cysteine-rich proteins in feathers and hair. BMC Evol. Biol. 2015, 15, 82. [CrossRef]

19. Alibardi, L.; Holthaus, K.B.; Sukseree, S.; Hermann, M.; Tschachler, E.; Eckhart, L. Immunolocalization of a histidine-rich epidermal differentiation protein in the chicken supports the hypothesis of an evolutionary developmental link between the embryonic subperiderm and feather barbs and barbules. PLOS ONE 2016, 11, e0167789. [CrossRef]

20. Lachner, J.; Ehrlich, F.; Mlitz, V.; Hermann, M.; Alibardi, L.; Tschachler, E.; Eckhart, L. Immunolocalization and phylogenetic profiling of the feather protein with the highest cysteine content. Protoplasma 2019, 256, 1257-1265. [CrossRef]

21. Steinert, P.M. A model for the hierarchical structure of the human epidermal cornified cell envelope. Cell Death Differ. 1995, 2, 33-40.

22. Mildner, M.; Jin, J.; Eckhart, L.; Kezic, S.; Gruber, F.; Barresi, C.; Stremnitzer, C.; Buchberger, M.; Mlitz, V.; Ballaun, C.; et al. Knockdown of filaggrin impairs diffusion barrier function and increases UV sensitivity in a human skin model. J. Investig. Dermatol. 2010, 130, 2286-2294. [CrossRef] [PubMed]

23. Mlitz, V.; Latreille, J.; Gardinier, S.; Jdid, R.; Drouault, Y.; Hufnagl, P.; Eckhart, L.; Guinot, C.; Tschachler, E. Impact of filaggrin mutations on Raman spectra and biophysical properties of the stratum corneum in mild to moderate atopic dermatitis. J. Eur. Acad. Dermatol. Venereol. 2012, 26, 983-990. [CrossRef] [PubMed]

24. McLean, W.H. Filaggrin failure-From ichthyosis vulgaris to atopic eczema and beyond. Br. J. Dermatol. 2016, 175 (Suppl. S2), 4-7. [CrossRef]

25. Contzler, R.; Favre, B.; Huber, M.; Hohl, D. Cornulin, a new member of the "fused gene" family, is expressed during epidermal differentiation. J. Investig. Dermatol. 2005, 124, 990-997. [CrossRef] [PubMed]

26. O'Keefe, E.J.; Hamilton, E.H.; Lee, S.C.; Steinert, P. Trichohyalin, a structural protein of hair, tongue, nail, and epidermis. J. Invest. Dermatol. 1993, 101, 65S-71S. 
27. Steinert, P.M.; Parry, D.A.; Marekov, L.N. Trichohyalin mechanically strengthens the hair follicle: Multiple cross-bridging roles in the inner root shealth. J. Biol. Chem. 2003, 278, 41409-41419. [CrossRef]

28. Basmanav, F.B.Ü.; Cau, L.; Tafazzoli, A.; Méchin, M.C.; Wolf, S.; Romano, M.T.; Valentin, F.; Wiegmann, H.; Huchenq, A.; Kandil, R.; et al. Mutations in three genes encoding proteins involved in hair shaft formation cause uncombable hair syndrome. Am. J. Hum. Genet. 2016, 99, 1292-1304. [CrossRef]

29. Mlitz, V.; Strasser, B.; Jaeger, K.; Hermann, M.; Ghannadan, M.; Buchberger, M.; Alibardi, L.; Tschachler, E.; Eckhart, L. Trichohyalin-like proteins have evolutionarily conserved roles in the morphogenesis of skin appendages. J. Investig. Dermatol. 2014, 134, 2685-2692. [CrossRef]

30. Mlitz, V.; Hussain, T.; Tschachler, E.; Eckhart, L. Filaggrin has evolved from an "S100 fused-type protein" (SFTP) gene present in a common ancestor of amphibians and mammals. Exp. Dermatol. 2017, 26, 955-957. [CrossRef]

31. Holthaus, K.B.; Strasser, B.; Sipos, W.; Schmidt, H.A.; Mlitz, V.; Sukseree, S.; Weissenbacher, A.; Tschachler, E.; Alibardi, L.; Eckhart, L. Comparative genomics identifies epidermal proteins associated with the evolution of the turtle shell. Mol. Biol. Evol. 2016, 33, 726-737. [CrossRef]

32. Holthaus, K.B.; Mlitz, V.; Strasser, B.; Tschachler, E.; Alibardi, L.; Eckhart, L. Identification and comparative analysis of the epidermal differentiation complex in snakes. Sci. Rep. 2017, 7, 45338. [CrossRef]

33. Holthaus, K.B.; Alibardi, L.; Tschachler, E.; Eckhart, L. Identification of epidermal differentiation genes of the tuatara provides insights into the early evolution of lepidosaurian skin. Sci. Rep. 2020, 10, 12844. [CrossRef]

34. Feng, S.; Stiller, J.; Deng, Y.; Armstrong, J.; Fang, Q.; Reeve, A.H.; Xie, D.; Chen, G.; Guo, C.; Faircloth, B.C.; et al. Dense sampling of bird diversity increases power of comparative genomics. Nature 2020, 587, 252-257. [CrossRef]

35. Nikolay, B.; Plieschnig, J.A.; Šubik, D.; Schneider, J.D.; Schneider, W.J.; Hermann, M. A novel estrogen-regulated avian apolipoprotein. Biochimie 2013, 95, 2445-2453. [CrossRef] [PubMed]

36. Nadeau, N.J.; Minvielle, F.; Ito, S.; Inoue-Murayama, M.; Gourichon, D.; Follett, S.A.; Burke, T.; Mundy, N.I. Characterization of Japanese quail yellow as a genomic deletion upstream of the avian homolog of the mammalian ASIP (agouti) gene. Genetics 2008, 178, 777-786. [CrossRef]

37. Fischer, H.; Eckhart, L.; Mildner, M.; Jaeger, K.; Buchberger, M.; Ghannadan, M.; Tschachler, E. DNase1L2 degrades nuclear DNA during corneocyte formation. J. Investig. Dermatol. 2007, 127, 24-30. [CrossRef] [PubMed]

38. Ito, T.; Mori, T. Peridermal granules of the chick embryo, histochemical, ultrastructural and immuno-electron microscopical study. Tohoku J. Exp. Med. 1987, 151, 169-180. [CrossRef] [PubMed]

39. Alibardi, L.; Mlitz, V.; Eckhart, L. Immunolocalization of scaffoldin, a trichohyalin-like protein, in the epidermis of the chicken embryo. Anat. Rec. 2015, 298, 479-487. [CrossRef] [PubMed]

40. Clark, G.A., Jr. Occurrence and timing of egg teeth in birds. Wilson Bull. 1961, 73, 268-278.

41. Richardson, R.J.; Dixon, J.; Jiang, R.; Dixon, M.J. Integration of IRF6 and Jagged2 signalling is essential for controlling palatal adhesion and fusion competence. Hum. Mol. Genet. 2009, 18, 2632-2642. [CrossRef]

42. Liu, H.; Duncan, K.; Helverson, A.; Kumari, P.; Mumm, C.; Xiao, Y.; Carlson, J.C.; Darbellay, F.; Visel, A.; Leslie, E.; et al. Analysis of zebrafish periderm enhancers facilitates identification of a regulatory variant near human KRT8/18. Elife 2020, 9, e51325. [CrossRef] [PubMed]

43. Sawyer, R.H.; Rogers, L.; Washington, L.; Glenn, T.C.; Knapp, L.W. Evolutionary origin of the feather epidermis. Dev. Dyn. 2005, 232, 256-267. [CrossRef] [PubMed]

44. Takase, T.; Hirai, Y. Identification of the C-terminal tail domain of AHF/trichohyalin as the critical site for modulation of the keratin filamentous meshwork in the keratinocyte. J. Dermatol. Sci. 2012, 65, 141-148. [CrossRef] [PubMed]

45. Yamamoto-Tanaka, M.; Makino, T.; Motoyama, A.; Miyai, M.; Tsuboi, R.; Hibino, T. Multiple pathways are involved in DNA degradation during keratinocyte terminal differentiation. Cell Death Dis. 2014, 5, e1181. [CrossRef] 